\title{
Influence of dimethyl ether addition on the oxidation of acetylene in the absence and presence of NO
}

\section{Lorena Marrodán \\ Laura Berdusán \\ Verónica Aranda \\ Ángela Millera \\ Rafael Bilbao \\ María U.}

uxue@unizar.es

Aragón Institute of Engineering Research (I3A), Department of Chemical and Environmental Engineering, University of Zaragoza, C/ Mariano Esquillor, S/N, 50018 Zaragoza, Spain

*Corresponding author.

\begin{abstract}

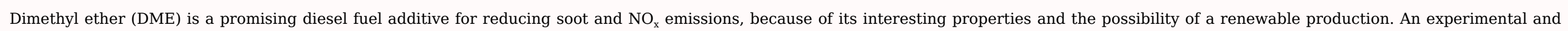

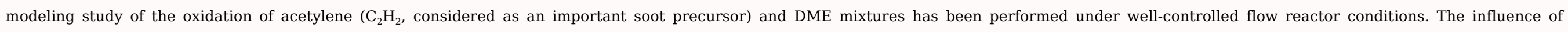

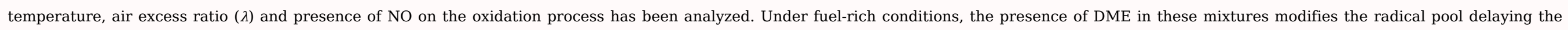

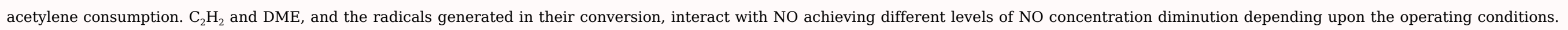

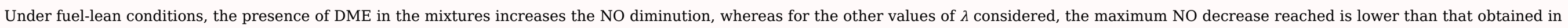
the case of pure acetylene.
\end{abstract}

Keywords: Dimethyl ether; $\mathrm{C}_{2} \mathrm{H}_{2}$-DME mixtures; Oxidation; Nitrogen oxides

\section{Introduction}

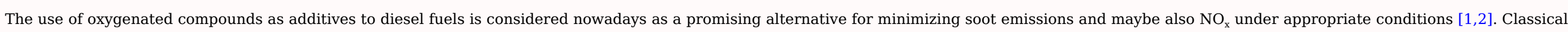

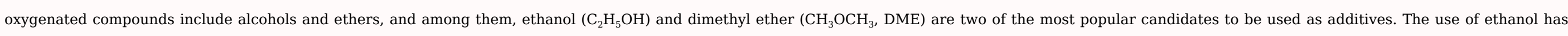

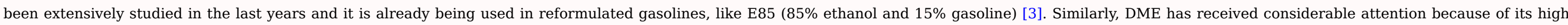

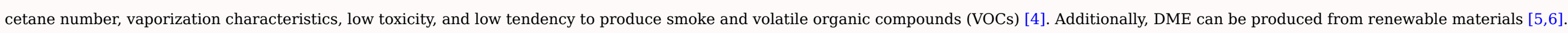

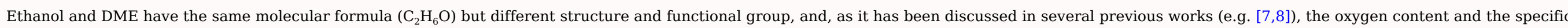

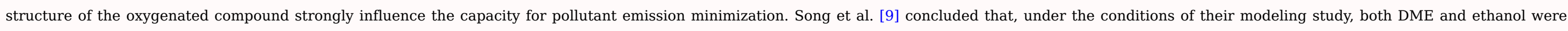

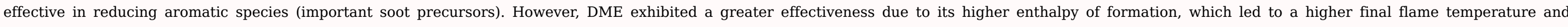

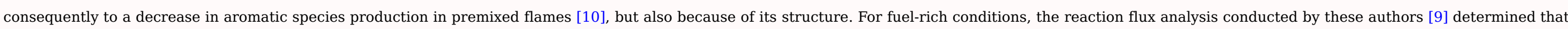

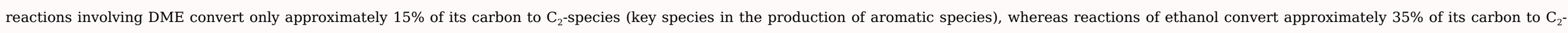
species. 


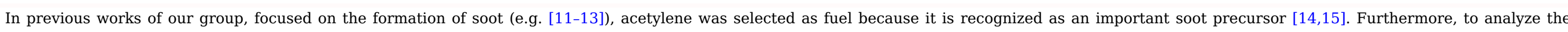

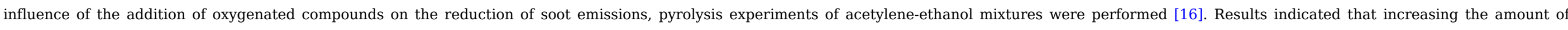

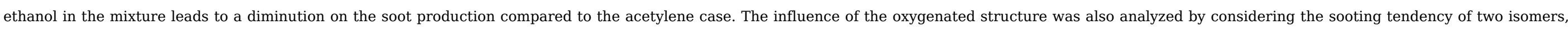
ethanol and DME [17], and the origin of both carbon and, in particular, oxygen appears to be critic for the formation of soot. DME has no C

C bonds and this fact can be the reason for DME to produce less soot than ethanol.

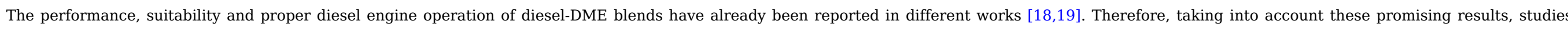
under well-controlled laboratory conditions may help to understand the influence of DME addition on the behavior of soot precursors in the overall oxidation process.

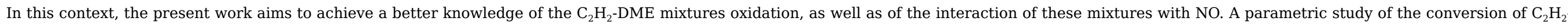

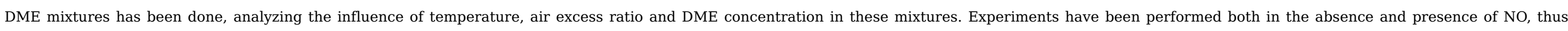

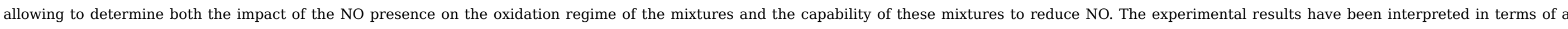
detailed kinetic mechanism built up from different individual reaction subsets taken from literature.

\section{Experimental}

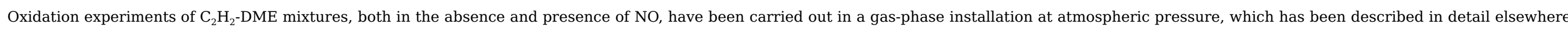
(e.g. [7]) and, therefore, only a brief description is given here.

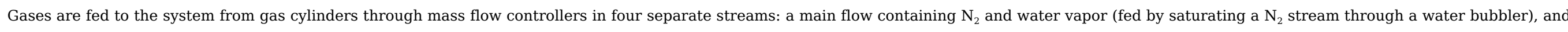

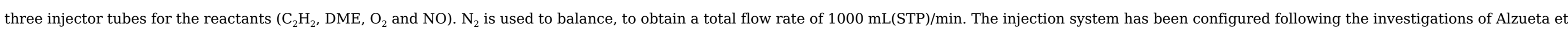
al. [20].

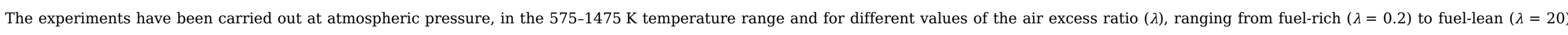

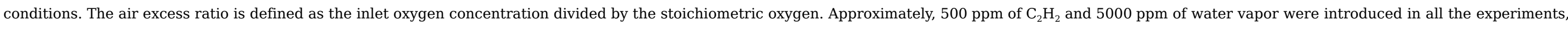
whereas for DME, two different amounts, 50 and 200 ppm, have been used. Table 1 lists the conditions of the different experiments.

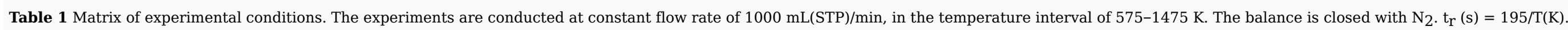

\begin{tabular}{|c|c|c|c|c|c|c|c|}
\hline Set & $\lambda$ & $\mathrm{C}_{2} \mathrm{H}_{2}(\mathrm{ppm})$ & DME (ppm) & $\mathrm{O}_{2}(\mathrm{ppm})$ & NO (ppm) & $\mathrm{H}_{2} \mathrm{O}(\mathrm{ppm})$ & Sourcea \\
\hline 1 & 0.2 & 500 & 50 & 280 & 0 & 5000 & pw \\
\hline 2 & 0.2 & 500 & 200 & 370 & 0 & 5000 & pw \\
\hline 3 & 0.2 & 500 & 200 & 370 & 500 & 5000 & pw \\
\hline 4 & 0.2 & 500 & 0 & 250 & 500 & 7000 & [23] \\
\hline 5 & 0.7 & 500 & 50 & 980 & 0 & 5000 & pw \\
\hline 6 & 0.7 & 500 & 200 & 1295 & 0 & 5000 & pw \\
\hline 7 & 0.7 & 500 & 200 & 1295 & 500 & 5000 & pw \\
\hline 8 & 0.7 & 500 & 0 & 875 & 500 & 7000 & [23] \\
\hline 9 & 0.7 & 500 & 0 & 875 & 0 & 7000 & [22] \\
\hline 10 & 1 & 500 & 50 & 1400 & 0 & 5000 & pw \\
\hline
\end{tabular}




\begin{tabular}{|c|c|c|c|c|c|c|c|}
\hline 11 & 1 & 500 & 200 & 1850 & 0 & 5000 & pw \\
\hline 12 & 1 & 500 & 200 & 1850 & 500 & 5000 & pw \\
\hline 13 & 1 & 500 & 0 & 1250 & 500 & 7000 & [23] \\
\hline 14 & 20 & 500 & 50 & 28,000 & 0 & 5000 & pw \\
\hline 15 & 20 & 500 & 200 & 37,000 & 0 & 5000 & pw \\
\hline 16 & 20 & 500 & 200 & 37,000 & 500 & 5000 & pw \\
\hline 17 & 20 & 500 & 0 & 25,000 & 500 & 5000 & pw \\
\hline 18 & 20 & 500 & 0 & 25,000 & 0 & 7000 & [22] \\
\hline
\end{tabular}

a "pw" denotes present work.

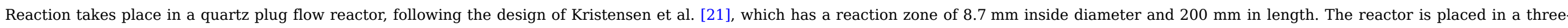

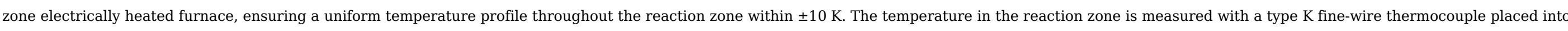

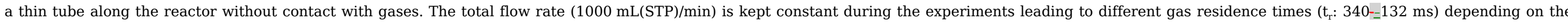
temperature in the isothermal reaction zone, being $t_{r}(s)=195 / T(K)$.

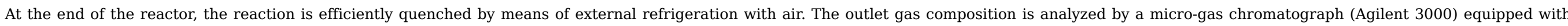

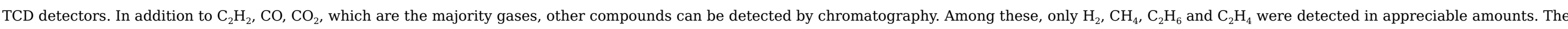

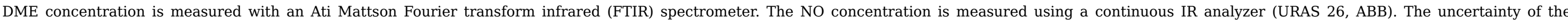
measurements is estimated as $\pm 5 \%$ but not less than $10 \mathrm{ppm}$, for both the continuous analyzers and the gas chromatograph.

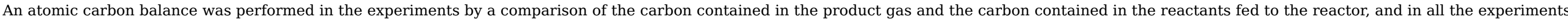
was closed within $100 \pm 10 \%$.

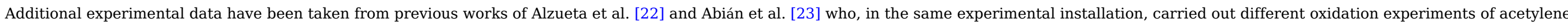
in the absence and presence of NO, respectively.

\section{Reaction mechanism}

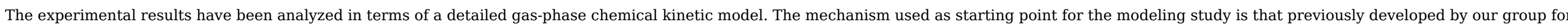

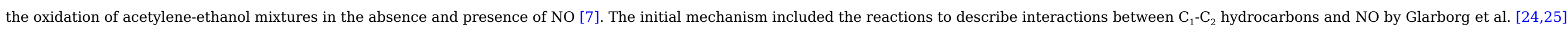
reactions for acetylene conversion by Alzueta et al. [22], and reactions for ethanol oxidation by Alzueta and Hernández [26].

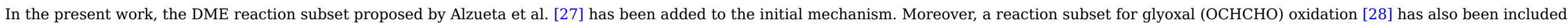

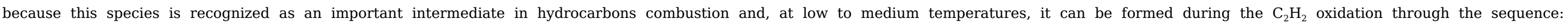

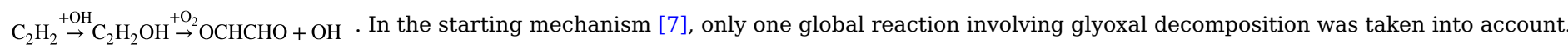

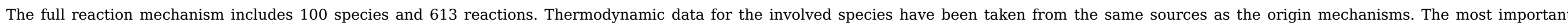
reactions are discussed below, and the final updated mechanism is provided as Supplementary material. The Chemkin version can be obtained directly from the authors.

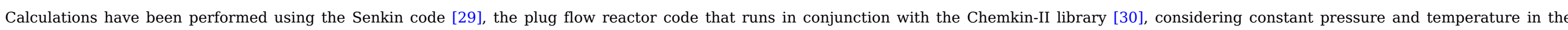
reaction zone.

\section{Results and discussion}




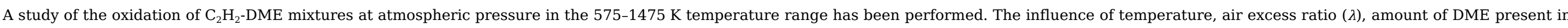

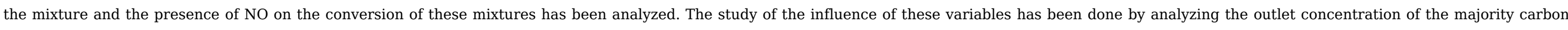
species $\left(\mathrm{C}_{2} \mathrm{H}_{2}\right.$, DME, $\mathrm{CO}$ and $\left.\mathrm{CO}_{2}\right)$ and NO. Other species $\left(\mathrm{CH}_{4}, \mathrm{C}_{2} \mathrm{H}_{6}\right.$ and $\left.\mathrm{C}_{2} \mathrm{H}_{4}\right)$ have also been detected but in very small amounts and, therefore, their results are not shown.

\section{1 $\mathrm{C}_{2} \mathrm{H}_{2}$-DME mixtures oxidation in the absence of NO}

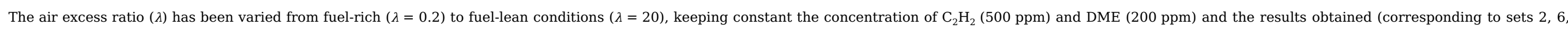
11 and 15 in Table 1) have been compared. Similar results (not shown) have been obtained for 50 ppm of DME (sets 1, 5, 10 and 14 in Table 1).

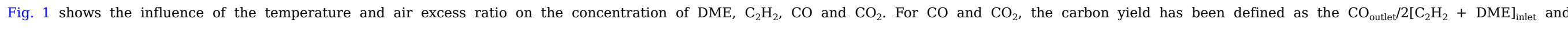

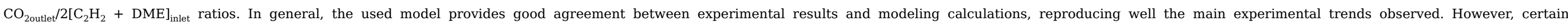

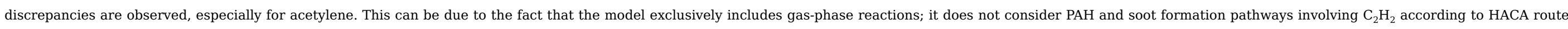
[14], which may be important under given conditions, such as the very fuel-rich conditions $(\lambda=0.2)$ of this work.

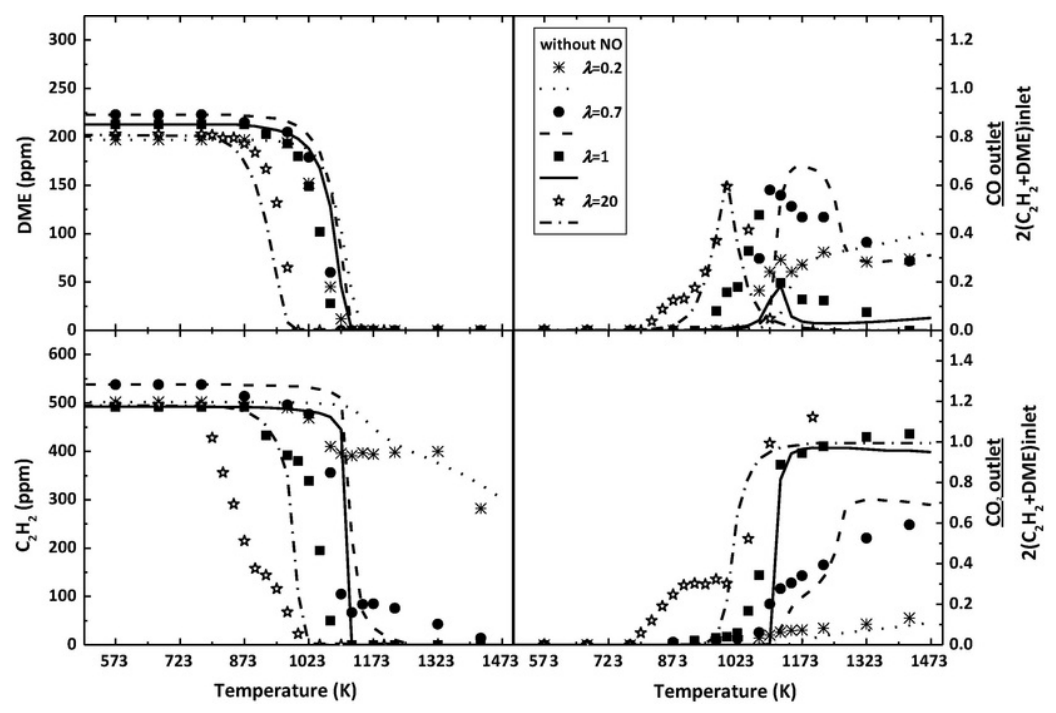

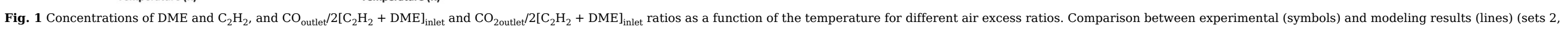
6, 11 and 15 in Table 1).

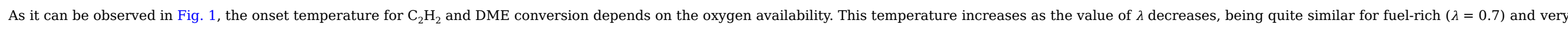

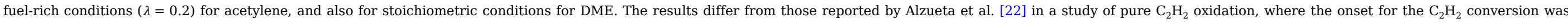

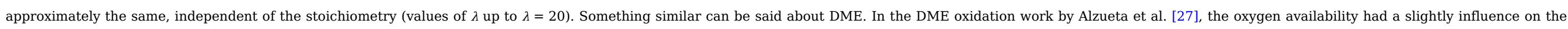
onset of pure DME oxidation. Thus, the results of the present work indicate an effective interaction of the compounds and/or their derivatives in the mixtures.

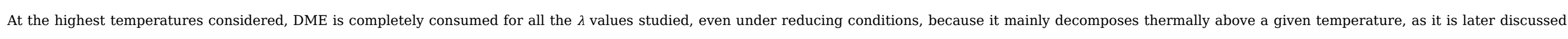

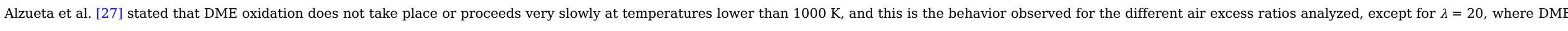

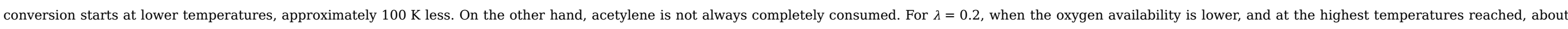

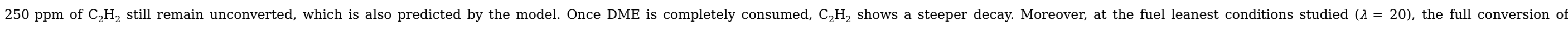

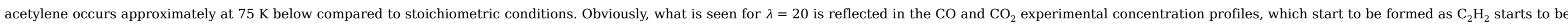




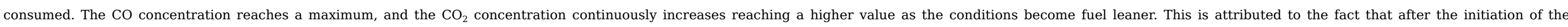

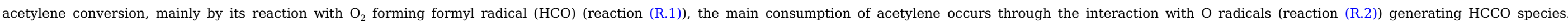
Afterwards, both $\mathrm{HCO}$ and $\mathrm{HCCO}$ give $\mathrm{CO}$ and subsequently $\mathrm{CO}_{2}$ (reactions (R.3)-(R.6)).

$\mathrm{C}_{2} \mathrm{H}_{2}+\mathrm{O}_{2} \rightleftharpoons \mathrm{HCO}+\mathrm{HCO}$

$\mathrm{C}_{2} \mathrm{H}_{2}+\mathrm{O} \rightleftharpoons \mathrm{HCCO}+\mathrm{H}$

$\mathrm{HCO}+\mathrm{M} \rightleftharpoons \mathrm{CO}+\mathrm{H}+\mathrm{M}$

$\mathrm{HCCO}+\mathrm{O}_{2} \rightleftharpoons \mathrm{CO}+\mathrm{CO}+\mathrm{OH}$

$\mathrm{HCCO}+\mathrm{O}_{2} \rightleftharpoons \mathrm{CO}+\mathrm{CO}_{2}+\mathrm{H}$

$\mathrm{CO}+\mathrm{OH} \rightleftharpoons \mathrm{CO}_{2}+\mathrm{H}$

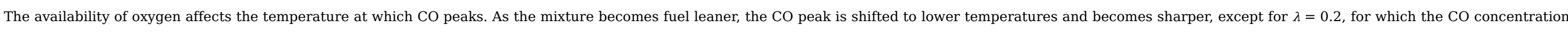
increases in all the temperature range studied.

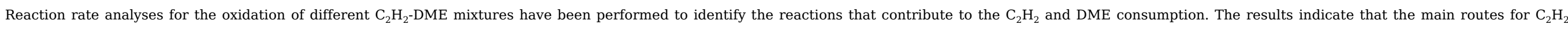

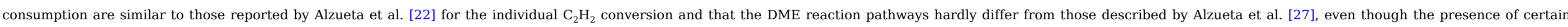
radicals (e.g. $\mathrm{OH}$ radicals) may increase the relevance of some of these routes as described below.

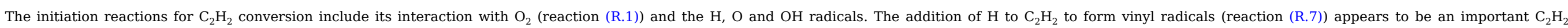
consumption reaction, especially for $\lambda=0.2,0.7$ and 1 .

$\mathrm{C}_{2} \mathrm{H}_{2}+\mathrm{H}(+\mathrm{M}) \rightleftharpoons \mathrm{C}_{2} \mathrm{H}_{3}(+\mathrm{M})$

This reaction is in competition with others involving interactions of $\mathrm{C}_{2} \mathrm{H}_{2}$ with O radicals (reactions (R.2) and (R.8)) and also with OH radicals, but with a minor relevance (reactions (R.9)-(R.11))

$\mathrm{C}_{2} \mathrm{H}_{2}+\mathrm{O} \rightleftharpoons \mathrm{CH}_{2}+\mathrm{CO}$

$\mathrm{C}_{2} \mathrm{H}_{2}+\mathrm{OH} \rightleftharpoons \mathrm{C}_{2} \mathrm{H}+\mathrm{H}_{2} \mathrm{O}$

$\mathrm{C}_{2} \mathrm{H}_{2}+\mathrm{OH} \rightleftharpoons \mathrm{HCCOH}+\mathrm{H}$

$\mathrm{C}_{2} \mathrm{H}_{2}+\mathrm{OH} \rightleftharpoons \mathrm{CH}_{2} \mathrm{CO}+\mathrm{H}$

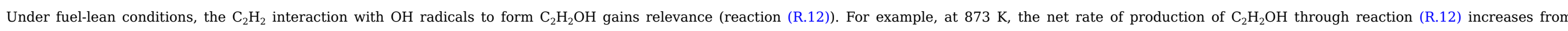

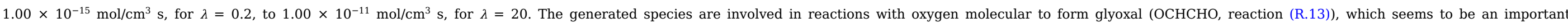

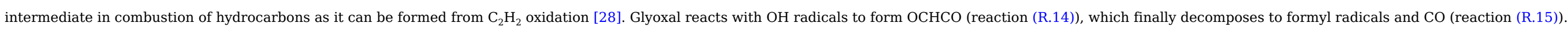

$\mathrm{C}_{2} \mathrm{H}_{2}(+\mathrm{M})+\mathrm{OH} \rightleftharpoons \mathrm{C}_{2} \mathrm{H}_{2} \mathrm{OH}(+\mathrm{M})$

$\mathrm{C}_{2} \mathrm{H}_{2} \mathrm{OH}+\mathrm{O}_{2} \rightleftharpoons \mathrm{OCHCHO}+\mathrm{OH}$

$\mathrm{OCHCHO}+\mathrm{OH} \rightleftharpoons \mathrm{OCHCO}+\mathrm{H}_{2} \mathrm{O}$

$\mathrm{OCHCO} \rightleftharpoons \mathrm{HCO}+\mathrm{CO}$

On the other hand, the conversion of DME is mainly initiated by its unimolecular decomposition:

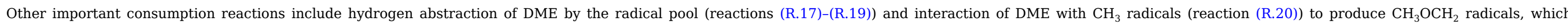
decompose to obtain formaldehyde (reaction (R.21)), that follows the $\mathrm{CH}_{2} \mathrm{O} \rightarrow \mathrm{HCO} \rightarrow \mathrm{CO} \rightarrow \mathrm{CO}_{2}$ reaction sequence.

$\mathrm{CH}_{3} \mathrm{OCH}_{3}+\mathrm{O} \rightleftharpoons \mathrm{CH}_{3} \mathrm{OCH}_{2}+\mathrm{OH}$ 


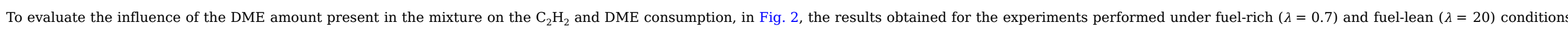

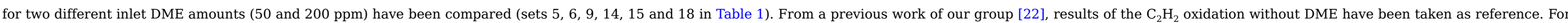
stoichiometric conditions, similar results (not shown) as those for $\lambda=0.7$ have been obtained.

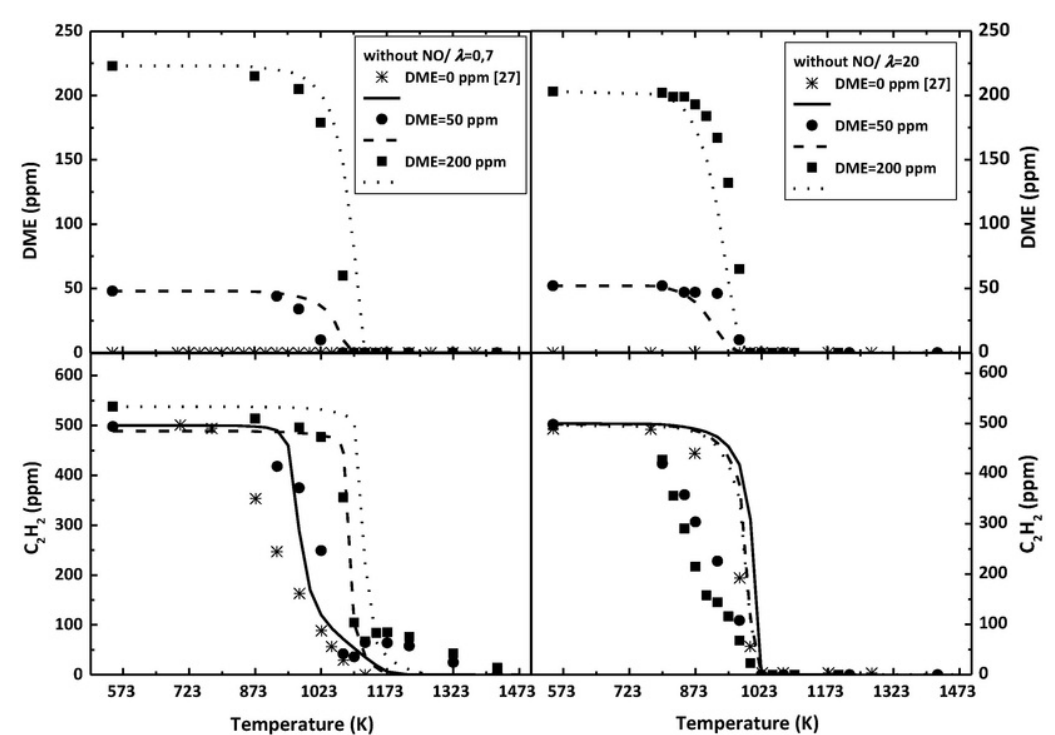

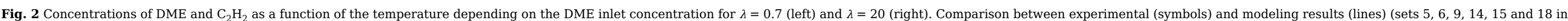
Table 1).

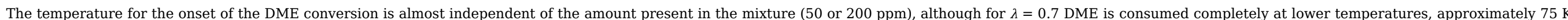
less in the experiments, for the DME lowest amount considered.

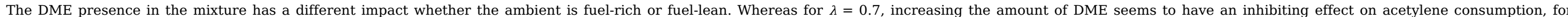
$\lambda=20$, the presence of DME shifts the $\mathrm{C}_{2} \mathrm{H}_{2}$ concentration profiles towards lower temperatures.

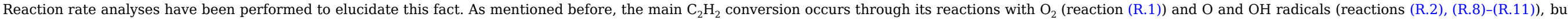

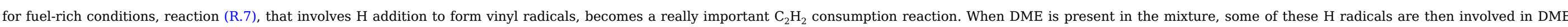

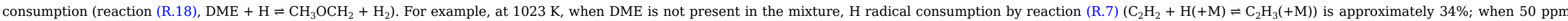

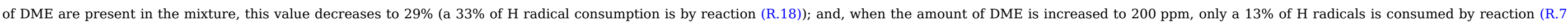

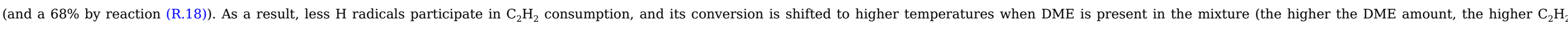
conversion temperatures).

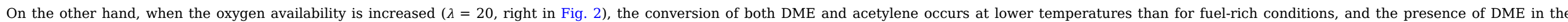

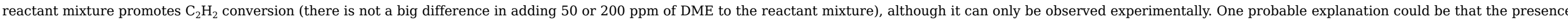

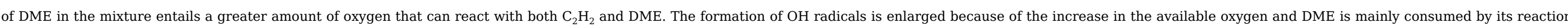




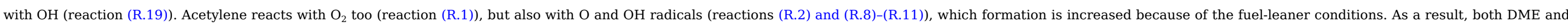

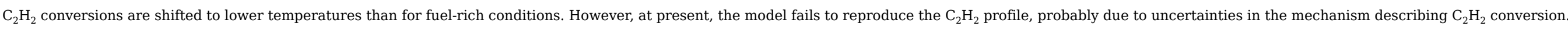

\section{2 $\mathrm{C}_{2} \mathrm{H}_{2}$-DME mixtures oxidation in the presence of NO}

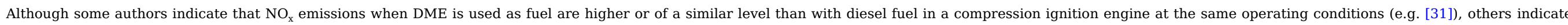

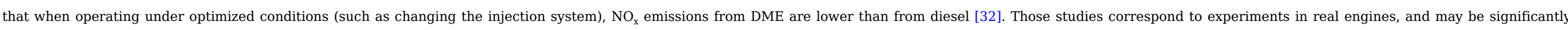

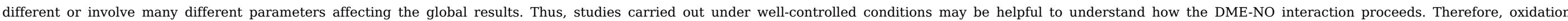
experiments of $\mathrm{C}_{2} \mathrm{H}_{2}$-DME mixtures in the presence of NO, for different air excess ratios, have also been carried out (Table 1).

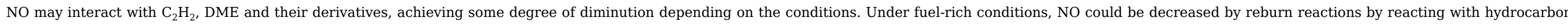

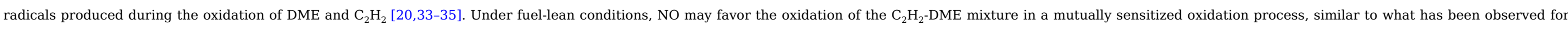
other compounds such as methane [36], ethanol and methanol [37].

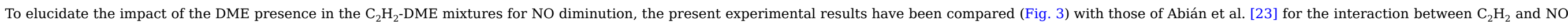

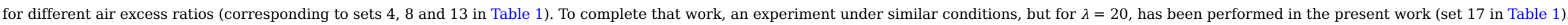

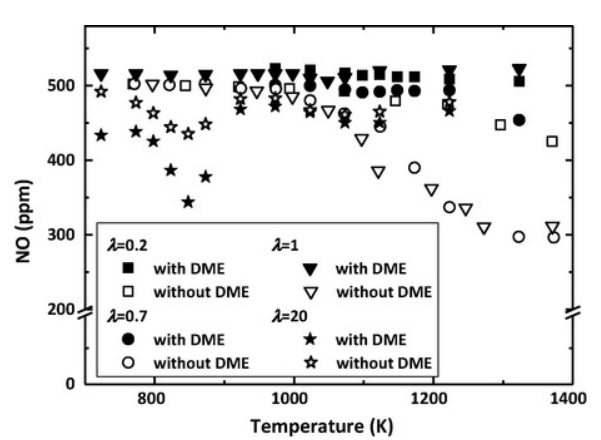

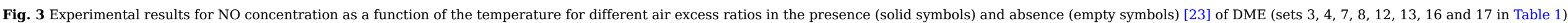

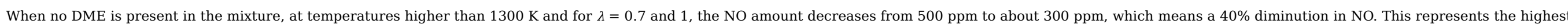

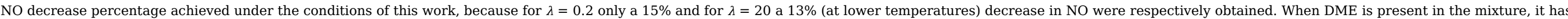
its main effect under fuel-lean conditions, when the NO decrease percentage rises from $13 \%$ up to $30 \%$.

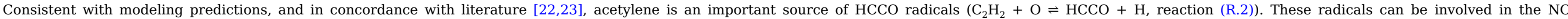

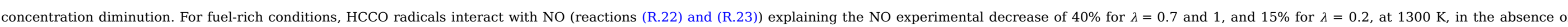

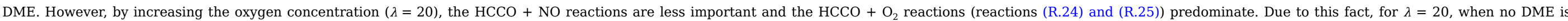

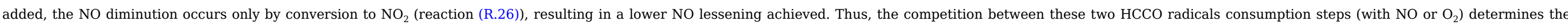
final level of NO lessening achieved.

$\mathrm{HCCO}+\mathrm{NO} \rightleftharpoons \mathrm{HCNO}+\mathrm{CO}$

$\mathrm{HCCO}+\mathrm{NO} \rightleftharpoons \mathrm{HCN}+\mathrm{CO}_{2}$

$\mathrm{HCCO}+\mathrm{O}_{2} \rightleftharpoons \mathrm{CO}_{2}+\mathrm{CO}+\mathrm{H}$

$\mathrm{HCCO}+\mathrm{O}_{2} \rightleftharpoons \mathrm{CO}+\mathrm{CO}+\mathrm{OH}$

$\mathrm{NO}+\mathrm{HO}_{2} \rightleftharpoons \mathrm{NO}_{2}+\mathrm{OH}$ 


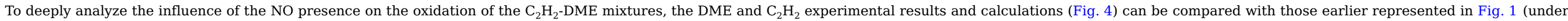
similar experimental conditions but in the absence of NO). Calculations predict reasonably well the trends obtained, with the exception of NO conversion under fuel-rich conditions, which is overestimated.

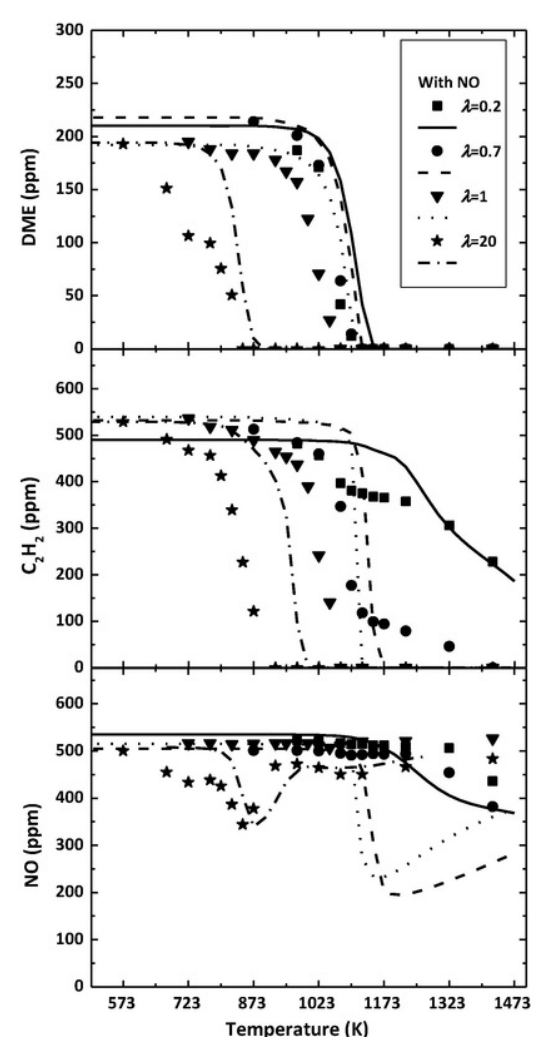

Fig. 4 Concentrations of DME, $\mathrm{C}_{2} \mathrm{H}_{2}$ and $\mathrm{NO}$ as a function of temperature for different air excess ratios. Comparison between experimental (symbols) and modeling results (lines) (sets 3, 7, 12 and 16 in Table 1).

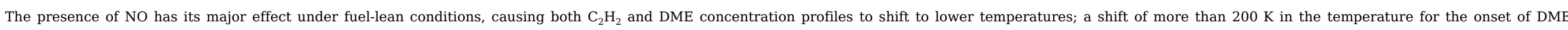
oxidation, similar to that observed by Alzueta et al. [27] in the study of pure DME oxidation in the presence of NO.

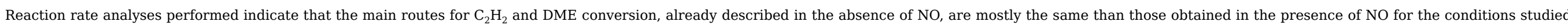

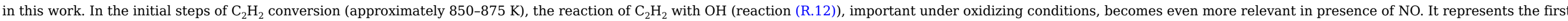

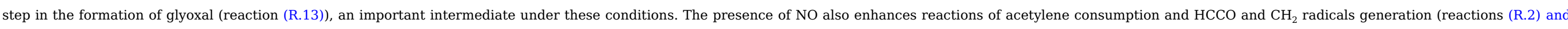
(R.8), respectively). As a result, the $\mathrm{C}_{2} \mathrm{H}_{2}$ oxidation in the presence of $\mathrm{NO}$ becomes faster under oxidizing conditions.

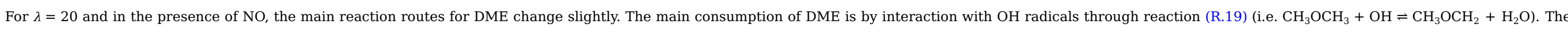

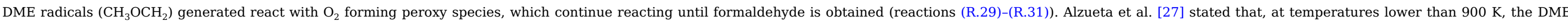

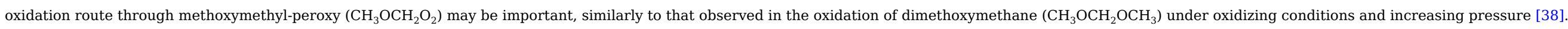


$\mathrm{CH}_{3} \mathrm{OCH}_{2}+\mathrm{O}_{2}(+\mathrm{M}) \rightleftharpoons \mathrm{CH}_{3} \mathrm{OCH}_{2} \mathrm{O}_{2}(+\mathrm{M})$

$\mathrm{CH}_{3} \mathrm{OCH}_{2} \mathrm{O}_{2} \rightleftharpoons \mathrm{CH}_{2} \mathrm{OCH}_{2} \mathrm{O}_{2} \mathrm{H}$

$\mathrm{CH}_{2} \mathrm{OCH}_{2} \mathrm{O}_{2} \mathrm{H} \rightleftharpoons \mathrm{CH}_{2} \mathrm{O}+\mathrm{CH}_{2} \mathrm{O}+\mathrm{OH}$

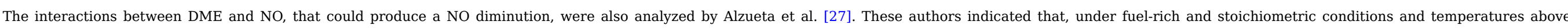

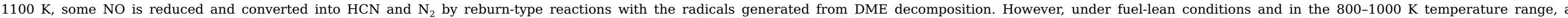
considerable fraction of $\mathrm{NO}$ is oxidized to $\mathrm{NO}_{2}$ (a $20 \%$ experimentally and a $40 \%$ based on modeling predictions), while no net $\mathrm{NO}_{\mathrm{x}}$ reduction is observed.

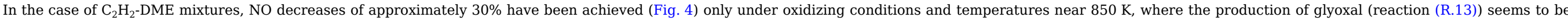
important. The glyoxal produced decomposes to formyl radicals (reactions (R.14) and (R.15)), and subsequently produces $\mathrm{HO}_{2}$ (reaction (R.32)).

$\mathrm{HCO}+\mathrm{O}_{2} \rightleftharpoons \mathrm{CO}+\mathrm{HO}_{2}$

Moreover, under these conditions of high oxygen availability ( $\lambda=20$, and NO presence), DME is initially converted into $\mathrm{CH}_{3} \mathrm{OCH}_{2}$ radicals through reaction ( $\mathrm{R} .33$ ), increasing the formation of $\mathrm{HO}_{2}$ radicals.

$\mathrm{CH}_{3} \mathrm{OCH}_{3}+\mathrm{O}_{2} \rightleftharpoons \mathrm{CH}_{3} \mathrm{OCH}_{2}+\mathrm{HO}_{2}$

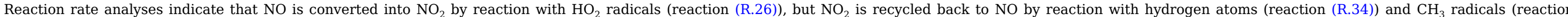
(R.35)), so no net reduction of $\mathrm{NO}_{\mathrm{x}}$ is achieved.

$\mathrm{NO}_{2}+\mathrm{H} \rightleftharpoons \mathrm{NO}+\mathrm{OH}$

$\mathrm{CH}_{3}+\mathrm{NO}_{2} \rightleftharpoons \mathrm{CH}_{3} \mathrm{O}+\mathrm{NO}$

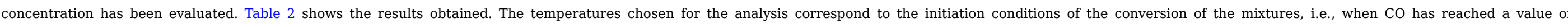
approximately $10 \mathrm{ppm}$

Table 2 Linear sensitivity coefficients for CO for the selected sets ${ }^{\mathrm{a}}$.

\begin{tabular}{|c|c|c|c|c|c|c|c|c|c|}
\hline \multirow[t]{2}{*}{ Reaction } & Set 2 & Set 3 & Set 6 & Set 7 & Set 10 & Set 11 & Set 12 & Set 15 & Set 16 \\
\hline & $1073 \mathrm{~K}$ & $1073 \mathrm{~K}$ & $1023 \mathrm{~K}$ & $1023 \mathrm{~K}$ & $973 \mathrm{~K}$ & $998 \mathrm{~K}$ & $998 \mathrm{~K}$ & $848 \mathrm{~K}$ & $798 \mathrm{~K}$ \\
\hline $\mathrm{C}_{2} \mathrm{H}_{2}+\mathrm{O}_{2} \rightleftharpoons \mathrm{HCO}+\mathrm{HCO}$ & 0.433 & 0.402 & 0.929 & 0.930 & 1.128 & 1.001 & 1.023 & 1.056 & 1.714 \\
\hline $\mathrm{C}_{2} \mathrm{H}_{2}+\mathrm{O} \rightleftharpoons \mathrm{HCCO}+\mathrm{H}$ & 0.018 & -0.004 & 0.025 & 0.003 & 0.060 & 0.029 & 0.008 & 0.025 & 0.053 \\
\hline $\mathrm{C}_{2} \mathrm{H}_{2}+\mathrm{H}(+\mathrm{M}) \rightleftharpoons \mathrm{C}_{2} \mathrm{H}_{3}(+\mathrm{M})$ & 0.011 & 0.009 & 0.039 & 0.039 & 0.114 & 0.047 & 0.057 & 0.013 & 0.037 \\
\hline $\mathrm{C}_{2} \mathrm{H}_{2} \mathrm{OH}+\mathrm{O}_{2} \rightleftharpoons \mathrm{OCHCHO}+\mathrm{OH}$ & - & - & - & - & - & - & - & 0.005 & 0.056 \\
\hline $\mathrm{OCHCHO}+\mathrm{OH} \rightleftharpoons \mathrm{OCHCO}+\mathrm{H}_{2} \mathrm{O}$ & - & - & - & - & - & - & - & 0.002 & 0.066 \\
\hline $\mathrm{C}_{2} \mathrm{H}_{3}+\mathrm{O}_{2} \rightleftharpoons \mathrm{CH}_{2} \mathrm{O}+\mathrm{HCO}$ & 0.072 & 0.081 & 0.038 & 0.055 & 0.055 & 0.024 & 0.042 & -0.001 & -0.008 \\
\hline $\mathrm{CH}_{3}+\mathrm{CH}_{3}(+\mathrm{M}) \rightleftharpoons \mathrm{C}_{2} \mathrm{H}_{6}(+\mathrm{M})$ & -0.185 & -0.212 & -0.063 & -0.074 & -0.084 & -0.049 & -0.063 & -0.104 & -0.256 \\
\hline $\mathrm{CH}_{3}+\mathrm{HO}_{2} \rightleftharpoons \mathrm{CH}_{3} \mathrm{O}+\mathrm{OH}$ & 0.007 & - & 0.021 & - & 0.183 & 0.037 & - & 0.286 & 0.001 \\
\hline \multirow[t]{2}{*}{$\mathrm{CH}_{4}+\mathrm{OH} \rightleftharpoons \mathrm{CH}_{3}+\mathrm{H}_{2} \mathrm{O}$} & 0.057 & 0.055 & 0.015 & 0.015 & 0.019 & 0.011 & 0.013 & 0.000 & 0.001 \\
\hline & 0.053 & 0.063 & 0.033 & 0.041 & 0.126 & 0.035 & 0.054 & 0.051 & 0.541 \\
\hline
\end{tabular}




\begin{tabular}{|c|c|c|c|c|c|c|c|c|c|}
\hline $\mathrm{CH}_{2} \mathrm{O}+\mathrm{OH} \rightleftharpoons \mathrm{HCO}+\mathrm{H}_{2} \mathrm{O}$ & & & & & & & & & \\
\hline $\mathrm{CH}_{2} \mathrm{O}+\mathrm{H} \rightleftharpoons \mathrm{HCO}+\mathrm{H}_{2}$ & 0.137 & 0.154 & 0.032 & 0.038 & 0.020 & 0.021 & 0.030 & 0.001 & 0.003 \\
\hline $\mathrm{CH}_{2} \mathrm{O}+\mathrm{CH}_{3} \rightleftharpoons \mathrm{HCO}+\mathrm{CH}_{4}$ & 0.387 & 0.405 & 0.107 & 0.112 & 0.046 & 0.067 & 0.076 & 0.005 & 0.009 \\
\hline $\mathrm{HCO}+\mathrm{M} \rightleftharpoons \mathrm{H}+\mathrm{CO}+\mathrm{M}$ & -0.006 & -0.012 & -0.007 & -0.035 & 0.068 & 0.001 & -0.043 & 0.037 & 0.017 \\
\hline $\mathrm{HCO}+\mathrm{O}_{2} \rightleftharpoons \mathrm{CO}+\mathrm{HO}_{2}$ & 0.006 & 0.009 & 0.007 & 0.017 & -0.067 & -0.001 & 0.021 & -0.038 & 0.035 \\
\hline $\mathrm{HCCO}+\mathrm{O}_{2} \rightleftharpoons \mathrm{CO}+\mathrm{CO}+\mathrm{OH}$ & 0.007 & 0.004 & 0.007 & 0.012 & -0.003 & 0.007 & 0.016 & 0.007 & 0.010 \\
\hline $\mathrm{CH}_{3} \mathrm{OCH}_{3} \rightleftharpoons \mathrm{CH}_{3} \mathrm{O}+\mathrm{CH}_{3}$ & 0.839 & 0.861 & 0.167 & 0.170 & 0.024 & 0.073 & 0.071 & - & - \\
\hline $\mathrm{CH}_{3} \mathrm{OCH}_{3}+\mathrm{H} \rightleftharpoons \mathrm{CH}_{3} \mathrm{OCH}_{2}+\mathrm{H}_{2}$ & -0.348 & -0.313 & -0.304 & -0.304 & -0.479 & -0.295 & -0.353 & -0.008 & -0.008 \\
\hline $\mathrm{CH}_{3} \mathrm{OCH}_{3}+\mathrm{O} \rightleftharpoons \mathrm{CH}_{3} \mathrm{OC} \mathrm{H}_{2}+\mathrm{OH}$ & -0.012 & -0.003 & -0.021 & -0.011 & -0.016 & -0.026 & -0.014 & -0.017 & 0.023 \\
\hline $\mathrm{CH}_{3} \mathrm{OCH}_{3}+\mathrm{OH} \rightleftharpoons \mathrm{CH}_{3} \mathrm{OCH}_{2}+\mathrm{H}_{2} \mathrm{O}$ & -0.057 & -0.067 & -0.041 & -0.051 & -0.159 & -0.043 & -0.069 & -0.033 & 0.831 \\
\hline $\mathrm{CH}_{3} \mathrm{OCH}_{3}+\mathrm{CH}_{3} \rightleftharpoons \mathrm{CH}_{3} \mathrm{OCH}_{2}+\mathrm{CH}_{4}$ & 0.063 & 0.065 & 0.024 & 0.024 & 0.007 & 0.016 & 0.016 & 0.002 & 0.000 \\
\hline $\mathrm{CH}_{3} \mathrm{OCH}_{2} \rightleftharpoons \mathrm{CH}_{3}+\mathrm{CH}_{2} \mathrm{O}$ & - & - & - & - & -0.001 & - & 0.000 & -0.026 & 0.140 \\
\hline $\mathrm{CH}_{3} \mathrm{OCH}_{3}+\mathrm{O}_{2}(+\mathrm{M}) \rightleftharpoons \mathrm{CH}_{3} \mathrm{OCH}_{2} \mathrm{O}_{2}(+\mathrm{M})$ & - & - & - & - & - & - & - & 0.006 & -0.035 \\
\hline $\mathrm{CH}_{3} \mathrm{OCH}_{2}+\mathrm{O}_{2} \rightleftharpoons \mathrm{CH}_{2} \mathrm{O}+\mathrm{CH}_{2} \mathrm{O}+\mathrm{OH}$ & - & - & - & - & - & - & - & 0.007 & -0.041 \\
\hline $\mathrm{CH}_{2} \mathrm{OCH}_{2} \mathrm{O}_{2} \mathrm{H} \rightleftharpoons \mathrm{CH}_{2} \mathrm{O}+\mathrm{CH}_{2} \mathrm{O}+\mathrm{OH}$ & - & - & - & - & - & - & - & 0.001 & -0.027 \\
\hline $\mathrm{O}+\mathrm{OH} \rightleftharpoons \mathrm{O}_{2}+\mathrm{H}$ & 0.110 & 0.061 & 0.118 & 0.077 & 0.269 & 0.122 & 0.093 & 0.158 & 0.277 \\
\hline $\mathrm{H}+\mathrm{O}_{2}+\mathrm{N}_{2} \rightleftharpoons \mathrm{HO}_{2}+\mathrm{N}_{2}$ & 0.007 & 0.010 & 0.004 & 0.011 & -0.062 & 0.000 & 0.014 & -0.173 & -0.204 \\
\hline $\mathrm{CH}_{3}+\mathrm{NO} \rightleftharpoons \mathrm{HCN}+\mathrm{H}_{2} \mathrm{O}$ & - & -0.011 & - & -0.004 & - & - & -0.003 & - & -0.008 \\
\hline $\mathrm{CH}_{3}+\mathrm{NO} \rightleftharpoons \mathrm{H}_{2} \mathrm{CN}+\mathrm{OH}$ & - & 0.072 & - & 0.033 & - & - & 0.031 & - & 0.020 \\
\hline $\mathrm{C}_{2} \mathrm{H}_{3}+\mathrm{NO} \rightleftharpoons \mathrm{C}_{2} \mathrm{H}_{2}+\mathrm{HNO}$ & - & 0.005 & - & 0.011 & - & - & 0.014 & - & 0.080 \\
\hline $\mathrm{HCO}+\mathrm{NO} \rightleftharpoons \mathrm{HNO}+\mathrm{CO}$ & - & 0.004 & - & 0.019 & - & - & 0.024 & - & -0.022 \\
\hline $\mathrm{HCCO}+\mathrm{NO} \rightleftharpoons \mathrm{HCN}+\mathrm{CO}_{2}$ & - & -0.010 & - & -0.017 & - & - & -0.021 & - & -0.012 \\
\hline $\mathrm{CH}_{3}+\mathrm{NO}_{2} \rightleftharpoons \mathrm{CH}_{3} \mathrm{O}+\mathrm{NO}$ & - & 0.004 & - & 0.015 & - & - & 0.035 & - & 0.049 \\
\hline $\mathrm{NO}_{2}+\mathrm{H} \rightleftharpoons \mathrm{NO}+\mathrm{OH}$ & - & -0.002 & - & -0.007 & - & - & -0.015 & - & -0.069 \\
\hline
\end{tabular}

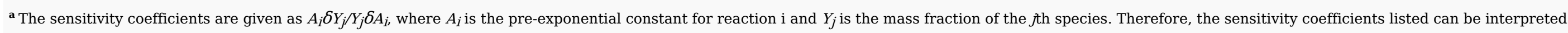




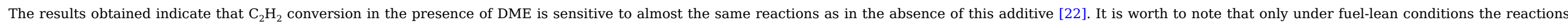

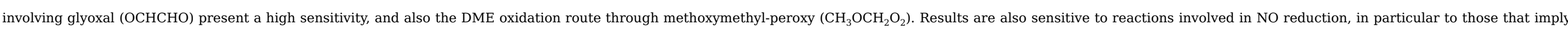
the competition between $\mathrm{HCCO}+\mathrm{NO}$ and $\mathrm{HCCO}+\mathrm{O}_{2}$, and also $\mathrm{CH}_{3}+\mathrm{NO}_{2}$.

\section{Conclusions}

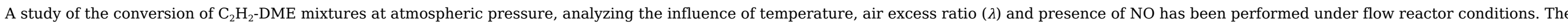

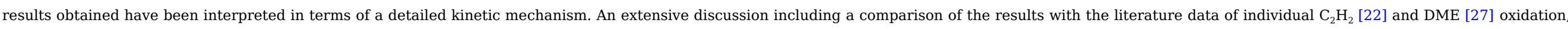
in the absence and presence of NO [23], has been made.

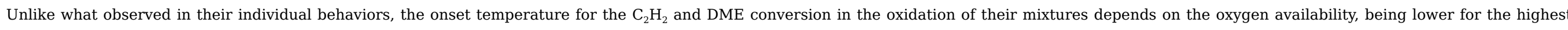

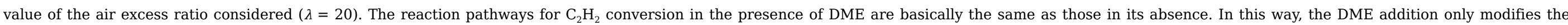

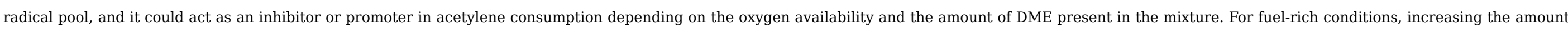

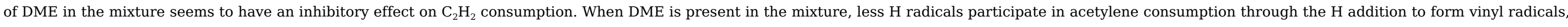

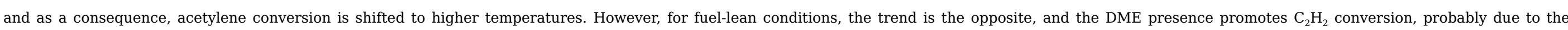
increasing of $\mathrm{O}$ and $\mathrm{OH}$ radical formation which is favored because of the fuel-leaner conditions. Therefore, both DME and $\mathrm{C}_{2} \mathrm{H}_{2}$ conversions are shifted to lower temperatures.

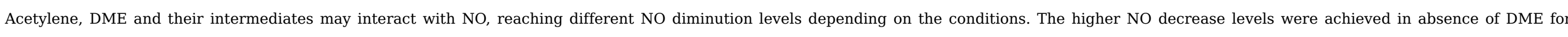

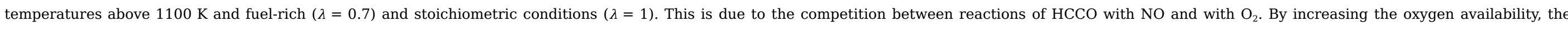

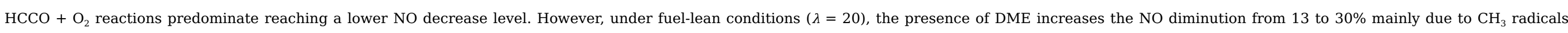
generated from its conversion, which can react with $\mathrm{NO}$ or $\mathrm{NO}_{2}$.

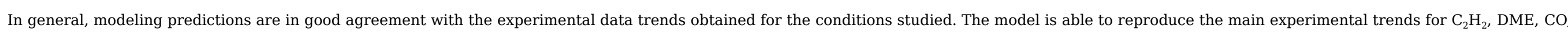

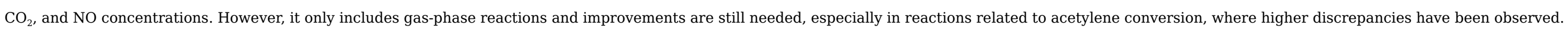

\section{Acknowledgements}

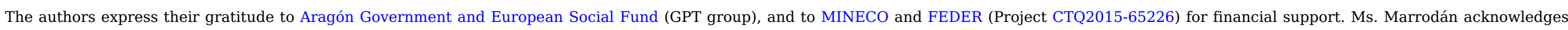
Aragón Government for the predoctoral grant awarded.

\section{Appendix A. Supplementary material}

Supplementary data associated with this article can be found, in the online version, at http://dx.doi.org/10.1016/j.fuel.2016.06.011.

\section{References}

[1] G. Yanfeng, L. Shenghua, G. Hejun, H. Tiegang and Z. Longbao, A new diesel oxygenate additive and its effects on engine combustion and emissions, Appl Therm Eng 27, $2007,202-207$.

[2] L.S. Tran, B. Sirjean, P. Glaude, R. Fournet and F. Battin-Leclerc, Progress in detailed kinetic modeling of the combustion of oxygenated components of biofuels, Energy 43, $2012,4-18$.

[3] W. Tutak, K. Lukács, S. Szwaja and Á. Bereczky, Alcohol-diesel fuel combustion in the compression ignition engine, Fuel 154, 2015, 196-206.

[4] R.J. Crookes and K.D.H. Bob-Manuel, RME or DME: a preferred alternative fuel option for future diesel engine operation, Energy Convers Manage 48, 2007 , $2971-2977$.

[5] Verbeek R, Van der Weide J. Global assessment of dimethyl-ether: comparison with other fuels. SAE Tech. Pap. $1997 ; 971607$.

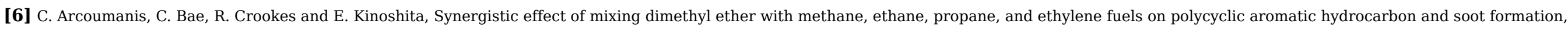


Fuel 87, 2008, 1014-1030.

[7] M. Abián, C. Esarte, A. Millera, R. Bilbao and M.U. Alzueta, Oxidation of acetylene-ethanol mixtures and their interaction with NO, Energy Fuels 22, $2008,3814-3823$.

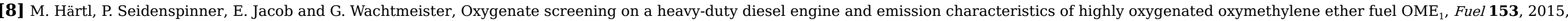
328-335.

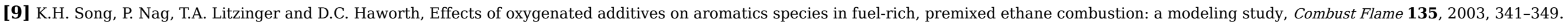

[10] I. Glassman and R.A. Yetter, Combustion, 4th ed., 2008, Academic Press; Bulington.

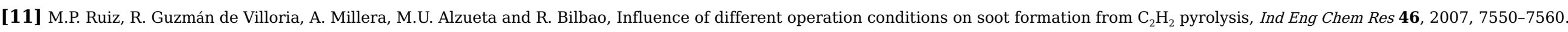

[12] T. Mendiara, M.P. Domene, A. Millera, R. Bilbao and M.U. Alzueta, An experimental study of the soot formed in the pyrolysis of acetylene, J Anal Appl Pyrolysis 74, 2005, 486-493.

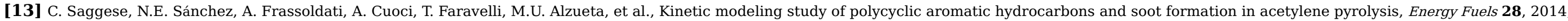
$1489-1501$.

[14] M. Frenklach, Reaction mechanism of soot formation in flames, Phys Chem Chem Phys 4, 2002, 2028-2037.

[15] H. Omidvarborna, A. Kumar and D.S. Kim, Recent studies on soot modeling for diesel combustion, Renew Sust Energy Rev 48, $2015,635-647$.

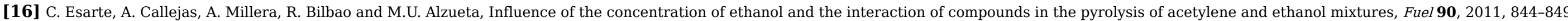

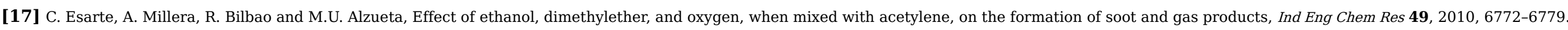

[18] Z. Bo, F. Weibiao and G. Jingsong, Study of fuel consumption when introducing DME or etanol into diésel engine, Fuel 85, 2006, 778-782.

[19] W. Ying, Z. Longbao and W. Hewu, Diesel emission improvements by the use of oxygenated DME/diesel blend fuels, Atmos Environ 40, $2006,2313-2320$.

[20] M.U. Alzueta, P. Glarborg and K. Dam-Johansen, Low temperature interactions between hydrocarbons and nitric oxide: an experimental study, Combust Flame 109, 1997, 25-36.

[21] P.G. Kristensen, P. Glarborg and K. Dam-Johansen, Nitrogen chemistry during burnout in fuel-staged combustion, Combust Flame 107, 1996, $211-222$.

[22] M.U. Alzueta, M. Borruey, A. Callejas, A. Millera and R. Bilbao, An experimental and modeling study of the oxidation of acetylene in a flow reactor, Combust Flame 152, 2008, 377-386.

[23] M. Abián, S.L. Silva, A. Millera, R. Bilbao and M.U. Alzueta, Effect of operating conditions on NO reduction by acetylene-ethanol mixtures, Fuel Process Technol 91, 2010, $1204-1211$.

[24] P. Glarborg, M.U. Alzueta, K. Dam-Johansen and J.A. Miller, Kinetic modeling of hydrocarbon/nitric oxide interactions in a flow reactor, Combust Flame 115, $1998,1-27$.

[25] P. Glarborg, M.U. Alzueta, K. Kjærgaard and K. Dam-Johansen, Oxidation of formaldehyde and its interaction with nitric oxide in a flow reactor, Combust Flame 132, $2003,629-638$.

[26] M.U. Alzueta and J.M. Hernández, Ethanol oxidation and its interaction with nitric oxide, Energy Fuels 16, 2002, 166-171.

[27] M.U. Alzueta, J. Muro, R. Bilbao and P. Glarborg, Oxidation of dimethyl ether and its interaction with nitrogen oxides, Isr J Chem 39, 1999 , 73-86.

[28] N. Faßheber, G. Friedrichs, P. Marshall and P. Glarborg, Glyoxal oxidation mechanism: implications for the reactions $\mathrm{HCO} \mathrm{O}_{2}$ and OCHCHO+HO${ }_{2}, J$ Phys Chem A 119, 2015, $7305-7315$.

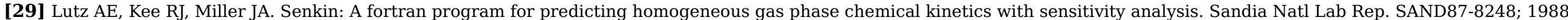

[30] Kee RJ, Rupley FM, Miller JA. Chemkin-II: A fortran chemical kinetics package for the analysis of gas-phase chemical kinetics. Sandia Lab Rep. SAND87-8215; 1991.

[31] D. Cipolat, Analysis of energy release and $\mathrm{NO}_{\mathrm{x}}$ emissions of a CI engine fueled on diesel and DME, Appl Therm Eng 27, 2007, 2095-2103. 
[32] S.H. Park and S.H. Yoon, Injection strategy for simultaneous reduction of $\mathrm{NO}_{\mathrm{x}}$ and soot emissions using two-stage injection in DME fueled engine, Appl Energy 143, 2015, 262-270.

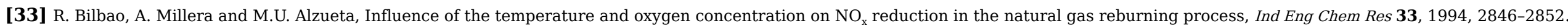

[34] J.A. Miller, S.J. Klippenstein and P. Glarborg, A kinetic issue in reburning: the fate of HCNO, Combust Flame 135, 2003, 357-362.

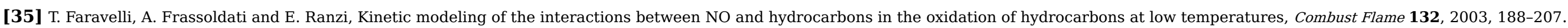

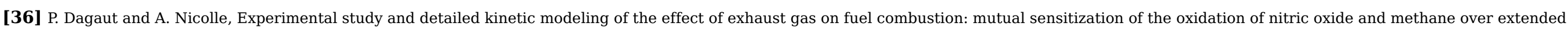
temperature and pressure ranges, Combust Flame 140, 2005, 161-171.

[37] P.H. Taylor, L. Cheng and B. Dellinger, The influence of nitric oxide on the oxidation of methanol and ethanol, Combust Flame 115, $1998,561-567$.

[38] L. Marrodán, E. Royo, A. Millera, R. Bilbao and M.U. Alzueta, High pressure oxidation of dimethoxymethane, Energy Fuels 29, 2015, 3507-3517.

\section{Appendix A. Supplementary material}

Multimedia Component 1

Supplementary data 1 L. Marrodán et al., Influence of dimethyl ether 573 addition on the oxidation of 574 acetylene in the absence and presence of NO, Fuel 2016.

\section{Highlights}

- Experimental and modeling study of the $\mathrm{C}_{2} \mathrm{H}_{2}$-DME mixtures oxidation

- For fuel-rich conditions, DME presence in the mixtures delays $\mathrm{C}_{2} \mathrm{H}_{2}$ consumption.

- For fuel-lean conditions, DME presence in the mixtures promotes $\mathrm{C}_{2} \mathrm{H}_{2}$ consumption.

- An effective NO diminution could be achieved depending on the oxygen availability.

- Competition between $\mathrm{HCCO}+\mathrm{NO}$ and $\mathrm{HCCO}+\mathrm{O}_{2}$ determines the final $\mathrm{NO}$ diminution.

\section{Queries and Answers}

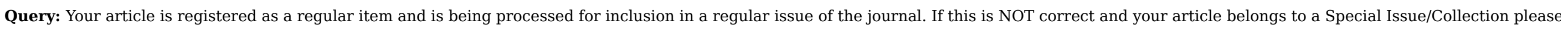
contact aravind.kumar@elsevier.com immediately prior to returning your corrections.

Answer: This article does NOT belong to a Special Issue.

Query: The author names have been tagged as given names and surnames (surnames are highlighted in teal color). Please confirm if they have been identified correctly.

Answer: The author names have been identified correctly.

Query: Please check edits made in affiliation, and correct if necessary.

Answer: The affiliation information is correct.

Query: Reaction (R.17) occurred more than once. Please check, and correct if necessary. 


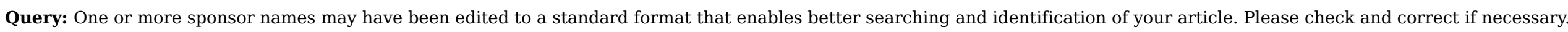
Answer: It is OK.

Query: Please check the multi media component, and the caption has been set correctly.

\section{Answer: It is NOT correct.}

The correct form is: "Marrodán et al., Influence of dimethyl ether addition on the oxidation of acetylene in the absence and presence of NO, Fuel 2016 "

Query: The country names of the Grant Sponsors are provided below. Please check and correct if necessary. 'MINECO' - 'Spain', 'FEDER' - 'Spain'.

Answer: The country names provided are the correct ones. 